\title{
CD8A wt Allele
}

National Cancer Institute

\section{Source}

National Cancer Institute. CD8A wt Allele. NCI Thesaurus. Code C104108.

Human CD8A wild-type allele is located in the vicinity of 2p11.2 and is approximately 24

$\mathrm{kb}$ in length. This allele, which encodes T-cell surface glycoprotein CD8 alpha chain protein, plays a role in antigen recognition by $\mathrm{T}$-cells. 